\title{
List of Books Received as of 1 August 2016
}

Each book is listed in two consecutive issues or, if assigned for review, until the review appears.

$*=$ Assigned for review

For book review guidelines, an up-to-date list of books available for review, or to contact the Book Review Editor, please visit:

http://www.astr.org/?page=TS_Submission_Guide

Anderegg, Michael. Lincoln and Shakespeare. Lawrence: University Press of Kansas, 2015. \$29.95 cloth, \$29.95 e-book.

Anoop, Maratt Mythili, and Varun Gulati eds. Scripting Dance in Contemporary India. Lanham, MD: Rowman \& Littlefield / Lexington Books, 2016. \$85 cloth, $\$ 84.99$ e-book.

Bingham, Emily. Irrepressible: The Jazz Age Life of Henrietta Bingham.

New York: Farrar, Straus \& Giroux, 2015. \$28 cloth, \$16 paper, \$9.99 e-book.

*Bogad, L. M. Tactical Performance: The Theory and Practice of Serious Play. London and New York: Routledge, 2016. \$135 cloth, \$29.95 paper, \$29.95 e-book.

Brosius, Peter, and Elissa Adams, eds. Key Change: New Musicals for Young Audiences. Minneapolis: University of Minnesota Press, 2016. \$70 cloth, \$19.95 paper, \$19.95 e-book.

*Cantu, Maya. American Cinderellas on the Broadway Musical Stage: Imagining the Working Girl from "Irene" to "Gypsy." Palgrave Studies in Theatre and Performance History. New York: Palgrave Macmillan, 2015. \$95 cloth.

Carlson, Marvin. Shattering Hamlet's Mirror: Theatre and Reality. Ann Arbor: University of Michigan Press, 2016. \$60 paper, $\$ 48.95$ e-book.

Carlyon, David. The Education of a Circus Clown: Mentors, Audiences, Mistakes. Palgrave Studies in Theatre and Performance History. New York: Palgrave Macmillan, 2016. \$99 cloth, $\$ 74.99$ e-book.

Colclough, Dyan. Child Labor in the British Victorian Entertainment Industry 1875-1914. Palgrave Studies in Theatre and Performance History.

New York: Palgrave Macmillan, 2016. \$95 cloth, \$69.99 e-book.

Crosby, Sara L. Poisonous Muse: The Female Poisoner and the Framing of Popular Authorship in Jacksonian America. Iowa City: Iowa University Press, 2016. $\$ 65$ paper, $\$ 65$ e-book.

Dietz, Dan. The Complete Book of 1970s Broadway Musicals. Lanham, MD: Rowman \& Littlefield, 2015. \$125 cloth, \$124.99 e-book.

Dietz, Dan. The Complete Book of 1980s Broadway Musicals. Lanham, MD: Rowman \& Littlefield, 2016. \$125 cloth, \$124.99 e-book. 
Dox, Donnalee. Reckoning with Spirit in the Paradigm of Performance. Ann Arbor: University of Michigan Press, 2016. \$85 cloth, \$39.50 paper, \$39.50 e-book.

Dunne, Will. The Architecture of Story: A Technical Guide for the Dramatic Writer. Chicago Guides to Writing, Editing, and Publishing. Chicago and New York: University of Chicago Press, 2016. \$55 cloth, \$18 paper, \$18 e-book.

García-Romero, Anne. The Fornes Frame: Contemporary Latina Playwrights and the Legacy of Maria Irene Fornes. Tucson: University of Arizona Press, 2016. \$24.95 paper, \$24.95 e-book.

*Garde, Ulrike, and Meg Mumford. Theatre of Real People: Diverse Encounters at Berlin's Hebbel am Ufer and Beyond. Methuen Drama Engage. London and New York: Bloomsbury Methuen Drama, 2016. \$104 cloth, \$29.95 paper, \$24.99 e-book.

Hand, Richard J., and Michael Wilson. Performing Grand-Guignol: Playing the Theatre of Horror. Exeter Performance Studies. Exeter: University of Exeter Press, 2016. \$120 cloth, \$36 paper.

Heddon, Deirdre, and Dominic Johnson, eds. It's All Allowed: The Performances of Adrian Howells. Intellect Live. Bristol: Intellect Ltd., 2016. \$28.50 paper.

*Heim, Caroline. Audience as Performer: The Changing Role of Theatre Audiences in the Twenty-first Century. London and New York: Routledge, 2016. \$125 cloth, \$47.95 paper, \$47.95 e-book.

Hindson, Catherine. London's West End Actresses and the Origins of Celebrity Charity, 1880-1920. Studies in Theatre History and Culture. Iowa City: University of Iowa Press, 2016. \$65 paper, \$65 e-book.

Hischak, Thomas S. Theatre as Human Action: An Introduction to Theatre Arts. 2d edition. Lanham, MD: Rowman \& Littlefield, 2016. \$95 cloth, \$45 paper, $\$ 44.99$ e-book.

Honea, Marc. Another Farewell to the Theatre: Occasional Writings, 2000-2013. The Lichtenbergian Press, 2014. \$19.99 paper.

Hughes, Jenny, and Helen Nicholson, eds. Critical Perspectives on Applied Theatre. Cambridge: Cambridge University Press, 2016. \$89.99 cloth, \$29.99 paper, \$24 e-book.

Johnston, Kirsty. Disability Theatre and Modern Drama: Recasting Modernism. Critical Companions. London and New York: Bloomsbury Methuen Drama, 2016. \$112 cloth, \$37.95 paper, \$24.99 e-book.

Josipovici, Gabriel. Hamlet: Fold on Fold. New Haven and London: Yale University Press, 2016. \$35 cloth, \$35 e-book.

Lavery, Carl, and Clare Finburgh, eds. Rethinking the Theatre of the Absurd: Ecology, the Environment and the Greening of the Modern Stage. Methuen Drama Engage. London and New York: Bloomsbury Methuen Drama, 2015. \$104 cloth, \$89.99 e-book.

*Lee, Esther Kim. The Theatre of David Henry Hwang. Critical Companions. London and New York: Bloomsbury Methuen Drama, 2015. \$94 cloth, \$29.95 paper, \$24.99 e-book. 
*Lennox, Patricia, and Bella Mirabella, eds. Shakespeare and Costume. London: Bloomsbury Arden Shakespeare, 2015. \$112 cloth, \$39.95 paper, \$32.99 e-book.

Lewis, Megan, and Anton Krueger, eds. Magnet Theatre: Three Decades of Making Space. Bristol, UK and Chicago: Intellect, 2016. \$45 paper.

Ley, Graham. Acting Greek Tragedy. Exeter: University of Exeter Press, 2014. \$85 cloth, \$27 paper, \$22 e-book.

Lindfors, Bernth. Ira Aldridge: The Last Years, 1855-1867. Rochester Studies in African History and the Diaspora. Rochester: University of Rochester Press, 2015. \$55 cloth.

*Loomis, Catherine, and Sid Ray, eds. Shaping Shakespeare for Performance: The Bear Stage. Shakespeare and the Stage. Madison, NJ: Fairleigh Dickinson University Press, 2016. \$85 cloth, $\$ 84.99$ e-book.

Mayo, Sandra M., and Elvin Holt. Stages of Struggle and Celebration: A Production History of Black Theatre in Texas. Jack and Doris Smothers Series in Texas History, Life, and Culture. Austin: University of Texas Press, 2016. \$75 cloth, \$29.95 paper, \$29.95 e-book.

Moran, James. The Theatre of D. H. Lawrence: Dramatic Modernist and Theatrical Innovator. Critical Companions. London and New York: Bloomsbury Methuen Drama, 2015. \$104 cloth, \$29.95 paper, \$24.99 e-book.

*Moreno, Iani del Rosario. Theatre of the Borderlands: Conflict, Violence, and Healing. Lanham, MD: Rowman \& Littlefield / Lexington Books, 2015. $\$ 90$ cloth.

*Nahshon, Edna, ed. New York's Yiddish Theater: From the Bowery to Broadway. New York: Columbia University Press, 2016. \$40 cloth, \$39.99 e-book.

Plastow, Jane, Yvette Hutchison, and Christine Matzke, eds. African Theatre 14: Contemporary Women. African Theatre Series. Woodbridge, Suffolk, UK and Rochester, NY: Boydell \& Brewer / James Currey, 2015. \$34.95 paper.

Porter, Jeff. Lost Sound: The Forgotten Art of Radio Storytelling. Chapel Hill: University of North Carolina Press, 2016. \$29.95 paper, \$28.99 e-book.

Profeta, Katherine. Dramaturgy in Motion: At Work on Dance and Movement Performance. Studies in Dance History. Madison: University of Wisconsin Press, 2015. \$26.95 paper, \$31.95 e-book.

Rice, Nicole R., and Margaret Aziza Pappano. The Civic Cycles: Artisan Drama and Identity in Premodern England. ReFormations: Medieval and Early Modern. Notre Dame: University of Notre Dame Press, 2015. \$42 paper.

*Sack, Daniel. After Live: Possibility, Potentiality, and the Future of Performance. Theater: Theory/Text/Performance. Ann Arbor: University of Michigan Press, 2015. \$75 cloth, \$34.95 paper, \$34.95 e-book.

Schechter, Joel. Eighteenth-Century Brechtians: Theatrical Satire in the Age of Walpole. Exeter Performance Studies. Exeter: University of Exeter Press, 2016. $\$ 95$ cloth.

Shannon, Sandra G., ed. August Wilson's Pittsburgh Cycle: Critical Perspectives on the Plays. Jefferson, NC: McFarland, 2016. \$40 paper, \$19.99 e-book. 


\section{Theatre Survey}

Shimazaki, Satoko. Edo Kabuki in Transition: From the Worlds of the Samurai to the Vengeful Female Ghost. New York: Columbia University Press, 2016. $\$ 60$ cloth, \$59.99 e-book.

Solga, Kim. Theatre \& Feminism. Theatre And. New York: Palgrave Macmillan, 2016. \$11 paper, \$11 e-book.

Taylor, Diana. Performance. Durham, NC: Duke University Press, 2016. \$84.95 cloth, \$23.95 paper, $\$ 23.95$ e-book.

Walsh, Fintan. Queer Performance and Contemporary Ireland: Dissent and Disorientation. Contemporary Performance InterActions. New York: Palgrave Macmillan, 2016. \$95 cloth, $\$ 69.99$ e-book.

Wong, Yutian. Contemporary Directions in Asian American Dance. Studies in Dance History. Madison: University of Wisconsin Press, 2016. \$45 cloth, \$55 e-book. 